\title{
SEVERANCE PAY AND THE OLDER WORKER: NEGOTIATED VERSUS LITIGATED OUTCOMES UNDER CANADIAN COMMON LAW
}

\author{
KENNETH WM. THORNICROFT ${ }^{*}$
}

The North American workforce is aging and workers are increasingly working beyond normal retirement age. Although mandatory retirement has largely been abandoned in Canada, employers still have the common law right to terminate employees without just cause by giving reasonable notice of dismissal. Where no, or insufficient, notice is given, the dismissed employee can file a civil action for wrongful dismissal. This article examines whether older workers are treated differently relative to younger workers in the assessment of reasonable notice. This question is examined in both an experimental negotiation simulation and by a statistical analysis of all Canadian appellate court decisions addressing reasonable notice issued during the 12-year period from 2000 to 2011.
La population active nord-américaine vieillit, et les travailleurs reportent de plus en plus l'âge normal de la retraite. Bien que le principe de la retraite obligatoire n'existe presque plus au Canada, les employeurs conservent tout de même le droit de licencier quelqu'un sans motif valable moyennant un préavis raisonnable. Si aucun préavis n'est donné ou si celui-ci est insuffisant, l'employé licencié peut alors déposer une action au civil pour congédiement injustifié. L'article examine si les travailleurs plus âgés sont traités différemment des travailleurs plus jeunes dans le calcul du préavis raisonnable. Cette question est étudiée, à la fois, dans le cadre d'une simulation de tentative de négociation et d'analyse statistique de toutes les décisions de cours d'appel en ce qui concerne les préavis raisonnables pour la période de 2000 à 2011.

\section{TABLE OF CONTENTS}

I. INTRODUCTION . . . . . . . . . . . . . . . . . . . . . . . 779

II. The ReAsonable Notice Doctrine $\ldots \ldots \ldots \ldots \ldots \ldots \ldots . \ldots . \ldots . \ldots 71$

III. REASONABLE NOTICE AND THE OLDER WORKER . . . . . . . . . . . . . . 783

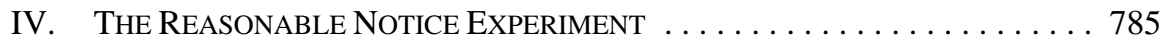

A. EXPERIMENTAL DESIGN AND PARTICIPANTS . . . . . . . . . 785

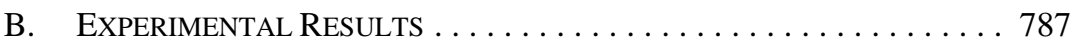

V. REASONABLE NOTICE DECISIONS ISSUED BY

CANADIAN APPELLATE COURTS $2000-2011 \ldots \ldots \ldots \ldots$. . . . . . . 788

A. The Judicial Database $\ldots \ldots \ldots \ldots \ldots \ldots \ldots \ldots$

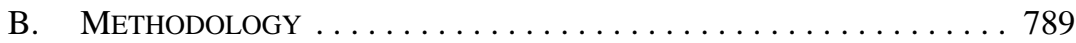

C. Descriptive StATISTICS . . . . . . . . . . . . . . . . . . . . . 791

D. REgRESSION RESUlTS . . . . . . . . . . . . . . . . . . . 792

VI. Discussion and Public Policy IMPLications $\ldots \ldots \ldots \ldots \ldots \ldots \ldots$

\section{INTRODUCTION}

The North American workforce is aging and this trend is expected to continue in the shortto medium-term. ${ }^{1}$ As of June 2014, 19.5 percent of the Canadian workforce was 55 years of

LLB/JD, PhD, Barrister \& Solicitor, Professor of Law \& Employment Relations, Peter B Gustavson School of Business, University of Victoria. I wish to acknowledge the contributions of two anonymous reviewers. Of course, any errors or omissions in this article remain my sole responsibility.

1 For Canadian data see Canada, National Seniors Council, Report on the Labour Force Participation of Seniors and Near Seniors, and Intergenerational Relations (Gatineau: Human Resources and Skills Development Canada, October 2011), online: <www.seniorscouncil.gc.ca/eng/research_publications/ labour_force/labour_force_participation.pdf $>$ [National Seniors Council Report]. For a review of the 
age or older and this same cohort represented 18.9 percent of all full-time employees. ${ }^{2}$ Employment and Social Development Canada reports that in 2012, 12 percent of those age 65 or older were working in paid employment, ${ }^{3}$ and estimates that by 2036 approximately 18.7 percent of employees will be 55 or older. ${ }^{4}$ A similar pattern prevails in the United States. ${ }^{5}$ Older workers (for the purposes of this article, an older worker is defined as 50 years of age or more) are increasingly working past the conventional retirement age for various reasons including a desire to maintain the social connections that work entails, better health and longer life expectancies, and purely economic reasons such as high personal debt and diminished pension funds. ${ }^{6}$

Mandatory retirement (typically at age 65), once firmly enshrined in law, has now been largely abandoned as the federal government and the provinces and territories have amended their human rights statutes so that age is no longer defined as less than 65 years of age. ${ }^{7}$ Paradoxically, although these legislative amendments were triggered (at least in part) by a desire to protect older workers, in light of these amendments employers may increasingly choose to terminate older employees on a without cause basis by giving (or negotiating) reasonable notice of termination. Employees who are dismissed without just cause are entitled to either working notice (that is, they continue working for a defined period after which the employment relationship ends) or, absent proper notice, severance pay in lieu of notice. If the parties cannot agree on a notice period (or severance pay in lieu of notice), the dismissed employee can sue for wrongful dismissal. The dismissed employee's age is a factor in the judicial determination of the notice period, and undoubtedly also comes into play in a negotiated resolution of the employee's claim. ${ }^{8}$ However, there is no specified

US situation, see Mitra Toossi, "Labor force projections to 2018: older workers staying more active” (2009) 132:11 Monthly Lab Rev 30.

2 Statistics Canada, "Table 282-0087: Labour force survey estimates (LFS), by sex and age group, seasonally adjusted and unadjusted," CANSIM (database), online: <www5.statcan.gc.ca/cansim/ a26?id=2820087 > [Table 282-0087].

3 Employment and Social Development Canada, “Work - Employment Rate," online: <well-being. esdc.gc.ca/misme-iowb/.3ndic.1t.4r@-eng.jsp?iid=13>. The employment rate for those 55 years of age and older stood at 35.7 percent in June 2014, whereas the employment rate for the 25- to 54-year old cohort was 80.6 percent: Table 282-0087, ibid.

$4 \quad$ National Seniors Council Report, supra note 1 at 5.

$5 \quad$ Randall W Eberts \& Richard A Hobbie, "Introduction” in Randall W Eberts \& Richard A Hobbie, eds, Older and Out of Work: Jobs and Social Insurance for a Changing Economy (Washington: National Academy of Social Insurance, 2008) 1.

$6 \quad$ Statistics Canada, "Retirement, health and employment among those 55 plus," by Jungwee Park, in Perspectives on Labour and Income, vol 23 No 1, Catalogue No 75-001-X (Ottawa: Statitsics Canada, 31 January 2011), online: <www.statcan.gc.ca/pub/75-001-x/2011001/pdf/11402-eng.pdf>.

This is not to say that mandatory retirement has been wholly eliminated in Canada. Employers can still justify mandatory retirement as a bona fide occupational requirement under human rights legislation and many Canadian human rights statutes include exemptions where mandatory retirement is a component of a bona fide retirement or pension plan. See New Brunswick (Human Rights Commission) v Potash Corporation of Saskatchewan Inc, 2008 SCC 45, [2008] 2 SCR 604 [New Brunswick (HRC)].

8 The overwhelming majority of civil claims are resolved short of trial. For example, in 2013 there were 54,015 civil claims filed in the British Columbia Supreme Court; however, in that same year there were only 459 civil trials indicating a 99 percent settlement rate. See Supreme Court of British Columbia, Annual Report (2013) at 51, 61, online: <www.courts.gov.bc.ca/supreme_court/about_the_supreme_ court/ annual_reports/2013\%20Annual\%20Report.pdf $>$. Similar settlement patterns prevail in other provincial and territorial trial courts - for example, in the province of Ontario, Canada's largest and busiest civil trial jurisdiction, Statistics Canada reports that, for the five fiscal years from 2009/10 to 2013/14, the ratio of "trial hearings" (which includes contested chambers matters and thus overstates the actual number of conventional "trials") in non-family civil matters before the Ontario Superior Court to the total number of active non-family civil cases was about 7 percent in each year, indicating that the vast majority of non-family civil matters before the Ontario Superior Court do not proceed to trial. See Statistics Canada, "Table 259-0011: Civil court survey, civil court cases (initiated, active and active with disposition) by level of court and type of case," CANSIM (database), online: <www5.statcan. 
formula for determining the reasonable notice period and notice determinations cannot be precisely predicted. The separate impact of age in the notice determination process, especially for older workers, is somewhat indeterminate since notice is assessed globally, taking into account all relevant factors. Although Canadian courts have stated that older workers are entitled to more notice than younger workers due to the labor market hurdles older workers presumably must overcome in their search for new employment (see Part III, "Reasonable Notice and the Older Worker"), the courts have never explicitly quantified, or even provided guidelines regarding, how much additional notice might be appropriate.

This article presents the results of a negotiation experiment in which both age and occupation were manipulated in an effort to determine which factor is more salient in the negotiation of notice periods. In addition, the separate impact of age on judicially determined reasonable notice awards was examined through a multivariate statistical analysis of all Canadian appellate court notice decisions issued during the 12-year period from 2000 to 2011. The results indicate that in both negotiated and adjudicated outcomes, older employees appear to be more favourably treated compared to younger employees, and that the combined effect of age and tenure is considerably more important than other factors such as occupational status or salary level.

This article is organized as follows: the reasonable notice doctrine is briefly summarized in Part II. Part III outlines the judicial decisions and previous empirical research regarding notice determinations for older workers. The negotiation experiment is discussed in Part IV and the statistical analysis of appellate court notice decisions for the period 2000 to 2011 is presented in Part V. Finally, Part VI provides summary observations and possible public policy implications.

\section{The Reasonable Notice Doctrine}

Canadian employees, unlike their American counterparts, are not governed by the employment-at-will doctrine pursuant to which an employment relationship may be summarily terminated without just cause or prior notice. ${ }^{9}$ A Canadian employee working under an indefinite contract of employment (that is, a contract with no pre-determined expiration date) is presumptively entitled to reasonable notice of termination. This entitlement is separate and apart from the statutory termination pay (or notice in lieu of payment) to which most Canadian employees are entitled. ${ }^{10}$ The reasonable notice doctrine

gc.ca/cansim/a26>; Statistics Canada, “Table 259-0014: Civil court survey, number of events in active civil court cases by level of court, type of case and type of event," CANSIM (database), online: $<$ www5.statcan.gc.ca/cansim/a26>.

9 For a concise summary of the employment-at-will doctrine see Judith Kish Ruud \& Wendy S Becker, "Employment-at-Will” in Robert K Prescott \& William Rothwell, eds, Encyclopedia of Human Resource Management: Short Entries, vol 1 (San Francisco: John Wiley \& Sons, 2012) 180 at 180-85.

10 The employer's implied common law contractual obligation to provide reasonable notice of termination is separate from the employer's statutory obligation to provide pay or notice under federal, provincial, and territorial employment standards legislation when terminating an employee without just cause. These individual termination provisions typically require the employer to give one week's wages or notice for each year of service up to a maximum of eight weeks. See e.g. Employment Standards Act, RSBC 1996, c 113, s 63 (compensation for length of service); Employment Standards Code, RSA 2000, c E-9, s 57 (termination pay). Additional notice or pay in lieu of notice provisions also apply in a mass lay off situation, usually triggered where 50 or more employees are dismissed within a defined time frame. Somewhat confusingly (and inaccurately), the individual statutory termination pay entitlements are sometimes called "severance pay" (and this is the term given to the required payment in lieu of notice in a mass lay off situation under Ontario’s Employment Standards Act, RSO 1990, c E14); in most jurisdictions the individual entitlement is known as "termination pay" or "wages in lieu of notice." 
does not apply if the employer has just cause for dismissal (for example, the employee has committed theft or some other serious misconduct) in which case the employee may be summarily terminated without any notice. The doctrine also does not apply if the parties have a fixed-term employment contract ${ }^{11}$ or have otherwise negotiated a lawful termination provision. $^{12}$

In circumstances where the employer does not have just cause for dismissal and, accordingly, the employee is entitled to reasonable notice, employers nevertheless often terminate the employee with little or no notice thereby denying the employee the opportunity to continue working to the end of the notice period. Summary dismissal without just cause is a breach of the employment contract (the breach being the failure to give proper notice rather than the termination itself) that triggers the employee's right to claim damages as severance pay in lieu of notice. ${ }^{13}$ The dismissed employee's severance pay entitlement is based on the employee's economic loss (for example, loss of income and other pecuniary benefits) that directly flows from the employer's refusal to allow the employee to work to the end of the notice period. The severance pay calculation requires an initial judicial determination of the reasonable notice period (typically expressed in months) that is then utilized to calculate the employee's pecuniary entitlement. ${ }^{14}$

The courts have determined that "the purpose of reasonable notice is to give the employee a fair opportunity to obtain re-employment instead of being thrown suddenly and unexpectedly upon the world." ${ }^{\prime 5}$ Canadian judges evaluate certain criteria - the so-called Bardal factors ${ }^{16}$ — when assessing a dismissed employee's prospects for re-employment and these factors guide the determination of an appropriate reasonable notice period:

Chambly (City) $v$ Gagnon, [1999] 1 SCR 8 (in the case of an unlawful termination of a fixed-term contract prior to its expiration, damages are assessed based on the compensation the employee would have earned during the balance of the agreement).

12 Machtinger v HOJ Industries Ltd, [1992] 1 SCR 986 [Machtinger].

13 It should be noted that an employer cannot lawfully choose, unless the employment contract expressly provides otherwise, to either give notice or pay severance in lieu of notice. Summary termination (that is, a failure to give reasonable notice), even if accompanied by an equivalent payment in lieu of proper notice, is nonetheless a breach of contract, though in that circumstance the employee may not have a viable damages claim. See Dunlop v BC Hydro \& Power Authority (1988), [1989] 2 WWR 518 (BCCA); Saalfeld v Absolute Software Corp, 2009 BCCA 18, 88 BCLR (4th) 244; Taylor v Dyer Brown (2004), 73 OR (3d) 358 (CA); Love v Acuity Investment Management Inc, 2011 ONCA 130, 277 OAC 15.

14 While severance pay in lieu of notice is typically expressed in months, statutory termination payments are expressed in weeks (see note 10, above). Generally speaking, the courts will deduct any statutory termination payments made to the employee from the ultimate severance pay award. See Roy v Metasoft Systems Inc, 2013 BCSC 1190, 50 BCLR (5th) 190 and the cases cited therein.

15 Cronk v Canadian General Insurance Co (1995), 25 OR (3d) 505 at 531 (CA), Weiler JA [Cronk]. See also: Honda Canada Inc v Keays, 2008 SCC 39, [2008] 2 SCR 362 at para 32 [Honda]; Schurman v Covered Bridge Recreation Inc, 2009 NBCA 1, 340 NBR (2d) 168 at para 28 [Schurman].

16 Bardal v The Globe \& Mail Ltd (1960), 24 DLR (2d) 140 (Ont HC) [Bardal]. The Supreme Court of Canada has repeatedly endorsed the Bardal factors: see Machtinger, supra note 12; Wallace v United Grain Growers Ltd, [1997] 3 SCR 701 [Wallace]; Honda, supra note 15. A search of the Canadian Legal Information Institute database conducted on 17 June 2015 indicated that the Bardal factors were applied in 1,010 other judicial decisions. Canadian trial judges have occasionally collapsed the Bardal factors into a "rule of thumb" whereby one month's notice is awarded for each year of service. Although appellate courts have clearly stated that there is, in fact, no such "rule" (see e.g. Pelech v Hyundai Auto Canada Inc (1991), 63 BCLR (2d) 24 at para 10 (CA); Minott v O'Shanter Development Company Ltd (1999), 42 OR (3d) 321 at 346 (CA)), some trial judges still use it as a starting point (and sometimes an endpoint): see e.g. Rodrigues v Shendon Enterprises Ltd, 2010 BCSC 941, [2010] BCJ No 1325 (QL); Nelson v Champion Feed Services Inc, 2010 ABQB 409, 30 Alta LR (5th) 162. 
There can be no catalogue laid down as to what is reasonable notice in particular classes of cases. The reasonableness of the notice must be decided with reference to each particular case, having regard to the character of the employment, the length of service of the servant, the age of the servant and the availability of similar employment, having regard to the experience, training and qualifications of the servant. ${ }^{17}$

Canadian courts have frequently observed that the determination of reasonable notice is more art than science ${ }^{18}$ and that reasonable notice depends on many factors. ${ }^{19}$ The Supreme Court of Canada has cautioned that the Bardal factors do not constitute an exhaustive list and that "[n]o one Bardal factor should be given disproportionate weight." ${ }^{20}$ Nevertheless, the Bardal factors are the principal considerations identified by Canadian judges when they are determining reasonable notice in a particular case. Regardless of how the various factors are weighed, as the law now stands, there is a rough upper reasonable notice limit of 24 months that cannot be exceeded absent exceptional circumstances. ${ }^{21}$

\section{REASONABLE NOTICE AND THE OLDER WORKER}

The reasonable notice doctrine is a common law rule designed to reduce the dislocative effects of employment termination. During the working notice period, an employee can search for new employment while still employed (albeit for a finite period). Accordingly, the Bardal factors should be weighed in terms of their impact on the dismissed employee's likely prospects for re-employment. ${ }^{22}$ Canadian courts assume that older workers face a comparatively more difficult labour market when confronted with involuntary job loss. ${ }^{23}$ The Supreme Court of Canada has stated that judges may take judicial notice of "the increasing difficulty with which one can find and maintain employment as one grows older" 24 and that "it is generally known that persons over 45 have more difficulty finding work than others." 25

These sentiments have been reflected in reasonable notice awards that were, apparently, increased by reason of the employee's comparatively older age. ${ }^{26}$ The term "apparent" emphasizes the fact that judges are instructed to assess reasonable notice globally without separately itemizing the individual components of the notice award. Thus, while an older employee's age may be noted as a factor justifying increased notice, the court will not specify the exact amount of the increase awarded on account of the employee's older age.

Bardal, ibid at 145.

See e.g. Wilmot v Ulnooweg Development Group Inc, 2007 NSCA 49, 253 NSR (2d) 376 at para 61; Beth v Advanced Micro Devices Inc, 2008 ONCA 686, 242 OAC 136 at para 10; Doucet v Spielo Manufacturing Inc, 2011 NBCA 44, 372 NBR (2d) 1.

See Wallace, supra note 16 at para 82; Honda, supra note 15 at paras 28-29.

Honda, supra note 15 at para 32.

Wallace, supra note 16 at para 109; Lowndes v Summit Ford Sales Ltd (2006), 206 OAC 55 at para 11. Compare Hussain v Suzuki Canada Ltd (2011), 100 CCEL (3d) 279 (Ont Sup Ct) [Hussain] (the Court fixed a 26-month notice period for a 65-year-old warehouse supervisor). Wallace, ibid at para 128; Re Rizzo \& Rizzo Shoes Ltd, [1998] 1 SCR 27 at para 25.

See e.g. Wallace, ibid; Kotecha v Affinia Canada ULC, 2013 ONSC 4817, [2013] OJ No 3360 (QL) at paras 20-22. On appeal, the 24.5-month notice award was reduced to 18 months but the Court nonetheless affirmed the trial judge's pessimistic view regarding the 70-year-old employee's job prospects (Kotecha $v$ Affinia Canada ULC, 2014 ONCA 411, 18 CCEL (4th) 137); see also Hussain, supra note 21.

Law v Canada (Minister of Employment and Immigration), [1999] 1 SCR 497 at para 101.

McKinney $v$ University of Guelph, [1990] 3 SCR 229 at 299.

See e.g. Slater $v$ Sandwell Inc (1994), 5 CCEL (2d) 308 (Ont Ct J (Gen Div)) [Slater]; Wallace, supra note 16; McLaren v Pacific Coast Savings Credit Union, 2001 BCCA 388, 89 BCLR (3d) 14; Lewis v PMC-Sierra Ltd, 2007 BCSC 1611, [2007] BCJ No 2386 (QL) [Lewis]; Mahesuram v Canac Kitchens Ltd, [2009] OJ No 221 (QL) (Sup Ct). 
Judges have justified older employees' longer notice periods for arguably legitimate and rational reasons (for example, employers will be reluctant to hire older workers because there would be fewer years to amortize training costs and employers will likely have to pay a higher wage, and may incur higher benefit costs) and for other less defensible reasons (for example, simple age discrimination or a desire to avoid an age discrimination claim if an older employee is hired but subsequently dismissed). ${ }^{27}$ Some Canadian courts have declared that older, long serving employees have a moral claim to greater notice. ${ }^{28}$ Although it has been argued that awarding older employees longer notice periods ultimately does them a disservice since employers will be even less inclined to hire older workers (and thus no older age factor should be built into the award), the courts have not been sympathetic to this argument. $^{29}$

The separate impact of age in the assessment of reasonable notice can be empirically determined using multivariate statistical analysis. A series of studies have examined age in the assessment of reasonable notice but these studies are now quite dated and all are based on trial, rather than, as it the case in this study, appellate awards. Appellate court decisions typically represent the views of three judges rather than a single judge and have greater precedential value than trial court decisions. Appellate awards define the parameters within which trial judges must operate when assessing reasonable notice. The results of these prior studies are mixed with some studies finding no age effect ${ }^{30}$ while others found age to be a positive and statistically significant factor in reasonable notice assessments. ${ }^{31}$ In each of these studies, age was coded as a continuous variable (the employee's actual age), rather than a categorical variable (that is, separate age ranges such as "under age 35") and, accordingly,

27 Cronk, supra note 15. Empirical evidence suggests that employers generally view older workers negatively: see e.g. Maurice J Mazerolle \& Gangaram Singh, "Economic and Social Correlates of ReEmployment Following Job Displacement: Evidence from 21 Plant Closures in Ontario” (2004) 63:3 American J Economics \& Sociology 717; Alicia H Munnell, Steven A Sass \& Mauricio Soto, "Employer Attitudes Towards Older Workers: Survey Results,” in Work Opportunities for Older Americans, series 3 (Boston: Center for Retirement Research, June 2006), online: <crr.bc.edu/wpcontent/uploads/2006/07/wob_3.pdf>; Hendrik P Van Dalen, Kène Henkens \& Joop Schippers, "Productivity of Older Workers: Perceptions of Employers and Employees" (2010) 36:2 Population \& Development Rev 309; Anne C Bal et al, "Examining Positive and Negative Perceptions of Older Workers: A Meta-Analysis” (2011) 66B:6 J Gerontology 687. Joanna N Lahey presents compelling evidence that older workers seeking new employment are victimized by pervasive age discrimination: “Age Discrimination and Hiring: Evidence from a Labor Market Experiment” in Eberts \& Hobbie, supra note 5 at 45. Many of the pervasive negative stereotypes held about older workers (for example, they lack motivation, are resistant to change or are less healthy than younger workers) are simply not empirically valid: see Thomas WH Ng \& Daniel C Feldman, "Evaluating Six Common Stereotypes About Older Workers With Meta-Analytical Data” (2012) 65:4 Personnel Psychology 821.

28 Ansari v BC Hydro \& Power Authority, [1986] 4 WWR 123 (BCSC) [Ansari]; Cronk, supra note 15; Bishop v Carleton Co-Operative Ltd (1996), 176 NBR (2d) 206 (CA); Bramble v Medis Health and Pharmaceutical Services Inc (1999), 214 NBR (2d) 111 (CA); Starks v Corner Brook Garage Ltd (2002), 220 Nfld \& PEIR 332 (NLSC (TD)); Lewis, supra note 26.

$29 \quad$ Slater, supra note 26; Taverner $v$ Seymour Golf \& Country Club (1994), 6 CCEL (2d) 316 (BCSC).

$30 \quad$ Steven L McShane, "Reasonable Notice Criteria in Common Law Wrongful Dismissal Cases" (1983) 38:3 Industrial Relations 618 [McShane, "Reasonable Notice Criteria”]; Tim Liznick, "Wrongful Dismissal: Determining Reasonable Notice” (1987) 5:4 Worklife Report 1.

31 Steven L McShane \& David C McPhillips, "Predicting Reasonable Notice in Canadian Wrongful Dismissal Cases” (1987) 41:1 Industrial \& Labor Relations Rev 108 [McShane \& McPhillips, "Predicting Reasonable Notice”]; Helen Lam \& Kay Devine, "Reasonable Notice for Wrongful Dismissal: Court versus Human Resource Decisions” (2001) 56:2 Industrial Relations 365. 
the courts' particular treatment of older employees was not examined. ${ }^{32}$ In addition, these studies are all based on sample, rather than population, data (typically drawn from decisions published in law reports) and the original samples were further reduced since the decisions frequently did not include specific information regarding the dismissed employee's age or other relevant factors. Studies utilizing only reported decisions may not be representative of the underlying population of all judicial decisions since reported decisions do not constitute a random sample of all relevant decisions. This creates a potential selectivity bias problem since one cannot be sure that the sample accurately represents the underlying population of all decided cases. Further, where cases are deleted from the statistical analysis due to missing data, the ultimate results may not be representative of the underlying population or the resulting sample may simply be too small to draw statistically meaningful conclusions. ${ }^{33}$ The multivariate statistical results reported in this article are based on Canadian appellate courts' reasonable notice decisions and the database represents something very close to the entire population of such decisions issued during the 2000 to 2011 time period.

\section{THE REASONABLE NOTICE EXPERIMENT}

The vast majority of civil claims, including wrongful dismissal claims, are settled not adjudicated. ${ }^{34}$ Ideally, this experiment would have been conducted utilizing practicing employment lawyers as negotiators; however, that approach simply was not a practical option. The results of the experiment may not reflect the outcomes that one might have obtained if the negotiators were practising lawyers. On the other hand, severance pay settlements are often concluded between the employer and employee directly without the assistance of legal counsel and, as will be seen, the "age effect" identified in the experiment was quite close to that observed in the analysis of the appellate court decisions. Consequently, informed lay persons can predict a likely judicial outcome in a particular case with reasonable accuracy.

\section{A. EXPERIMENTAL DESIGN AND PARTICIPANTS}

The experiment involved university business students assuming the role of legal counsel for either the dismissed employee or the employer. They were instructed to negotiate a severance pay agreement for an employee who was terminated without just cause. The experiment was conducted as a component of a business law course module on employment law. Prior to the commencement of the negotiation simulation, the students were briefed

32 There is one exception: Sandra Rollings-Magnusson, “Gender Implications of Wrongful Dismissal Judgments in Canada, 1994-2002” (2004) 41:1 Can Rev Sociology 27. Although this study partitioned the dismissed employees into five age categories (in seven-year increments commencing at 28 years of age), the data were analyzed using only mean (average) comparisons. The results indicated that notice awards increased by about 2 months as one moved from the lowest to the highest age category. Another study compared the mean notice awards for employees aged 45 to 55 years versus 55 to 65 years and found higher awards for the latter group but there were no controls for other relevant factors such as tenure, position and salary: Barry B Fisher, "Revisiting Reasonable Notice Periods in Wrongful Dismissal Cases 2006 Edition” (2007) 53 CCEL (3d) 60.

33 See e.g. McShane, "Reasonable Notice Criteria," supra note 30 (the original 199 case sample was reduced to 107 cases due to missing data); McShane \& McPhillips, "Predicting Reasonable Notice," supra note 31 (the 138 case sample was reduced to 102 cases); Liznick, supra note 30 (the 67 case sample was reduced to 44 cases); Lam \& Devine, supra note 31 (the 132 case sample was reduced to 75 cases).

$34 \quad$ See the data reported, supra note 8. 
(through class lecture/discussion and assigned readings) about the legal principles governing the determination of reasonable notice and the personal and economic factors (that is, the Bardal factors) that influence that determination.

The simulation materials contained information regarding a 10-year Vancouver based employee (the employee's gender was not specified) who was dismissed without cause by their employer, a large multinational pharmaceutical firm. The materials also included information regarding the employee's age (35 or 55 years of age), occupation (a sales representative earning $\$ 50,000$ per annum or a regional sales manager earning $\$ 90,000$ per annum), tenure (10 years in all cases), and education (an undergraduate chemistry degree and an MBA in all cases). Four separate versions of the simulation materials were distributed to the students who, in turn, were randomly assigned to their particular role and negotiating partner. The experiment was thus a 2 x 2 factorial design with age (35 or 55 years) and occupation (sales representative or regional sales manager) being the manipulated variables. Consistent with judicial pronouncements, the mean negotiated awards should be higher for older employees and for managers although, ex ante, one would not necessarily predict that age is necessarily a more powerful factor than occupation. Indeed, the Supreme Court of Canada has cautioned, "[n]o one Bardal factor should be given disproportionate weight."35

The simulation materials also contained thumbnail sketches of seven recent British Columbia Supreme Court decisions that spanned a continuum from 4 to 22 months' notice. The students were advised that the rough upper limit of reasonable notice was 24 months. The students were further advised that they were not required to reach a settlement and that the only issue to be negotiated was the employee's notice entitlement to be expressed, as is the legal convention, in a specified number of months. The students were given a settlement agreement form to complete and sign on behalf of their clients. The entire simulation including introductory remarks, negotiation and debriefing - typically took about 90 minutes to complete (the actual negotiations occupied about 30 minutes).

The negotiators consisted of 926 students — 550 undergraduate business students and 334 post-graduate students (either MBA or post-graduate business diploma students) for a total of 463 bargaining dyads. As previously noted, the students were instructed that they were not required to reach an agreement, and in 21 cases an agreement was not reached. Thus, the results reported here reflect 442 separate bargaining dyads (884 students) comprising 275 undergraduate dyads (550 students) and 167 post-graduate dyads (334 students). Due to provincial privacy law restrictions, information was not collected about the students' individual ages; however, the mean age of the undergraduate students (based on data gathered by the faculty) would be approximately 20 years versus approximately 35 years for the post-graduate students. The undergraduate students were a homogenous group in terms of age with almost all students being within a year or two of the 20-year age mark; the age range for the post-graduate students was significantly wider and is estimated to span from about 25 to 55 years. A series of statistical tests (known as t-tests) were conducted to determine if there were significant differences in negotiated outcomes between the undergraduate and post-graduate students. No statistically significant differences were found. Accordingly, the two student cohorts (undergraduate and post-graduate) were consolidated 
for purposes of the analyses. The student negotiators were evenly divided by gender (male $=444$; female $=440$ ). There were no statistically significant differences in negotiated outcomes as between male and female negotiators.

The settlement results were analyzed using the analysis of variance (ANOVA) statistical method. This technique is utilized to identify statistically significant differences between group means and to examine if there are any significant interaction effects between the variables of interest.

\section{B. EXPERIMENTAL RESULTS}

The experimental results are summarized in Table 1 (mean negotiated awards) and Table 2 (ANOVA results). As expected, the overall mean negotiated settlement for 55-year-old employees was about 41.5 percent higher than for 35-year-old employees (14.81 versus 10.47 months). Similarly, and consistent with a priori expectations, the mean negotiated award for sales managers was higher than for sales representatives but by a much smaller margin (13.18 versus 12.13 months - only an 8.7 percent margin). Not surprisingly, the largest mean negotiated notice award (15.47 months) was for the 55-year-old sales manager group (122 cases) whereas the lowest mean negotiated settlement (10.09 months) was for the 35-year-old sales representative group (98 cases).

The results reported in Table 1 indicate that age was a much more important factor than occupational status in determining the final negotiated notice awards. There was a modest difference in the negotiated notice awards for 35-year-old employees who were either sales representatives or sales managers (seven-tenths of a month) and a similar pattern prevailed for the 55-year-old cohort (the difference being 1.43 months). However, the 55 -year-old sales representatives and sales managers obtained, on average, settlements that were 3.95 and 4.68 months, respectively, higher than the 35-year-old sales representatives' and sales managers' average negotiated awards.

Table 1: Mean Negotiated Notice AWARds by EMPloyeE’s Age and OCCuPATion

\begin{tabular}{|l|l|c|c|c|}
\hline \multicolumn{1}{|c|}{ EMPLOYEE's AGE } & \multicolumn{1}{|c|}{$\begin{array}{c}\text { EMPLOYEe's } \\
\text { OCCUPATION }\end{array}$} & $\begin{array}{c}\text { MEAN Notice AWARD } \\
\text { (MONTHS) }\end{array}$ & $\begin{array}{c}\text { STANDARD } \\
\text { DEVIATION } \\
\text { (MONTHS) }\end{array}$ & N \\
\hline 35 years & & 10.47 & 2.51 & 215 \\
\hline 55 years & & 14.81 & 3.04 & 227 \\
\hline & & & & \\
\hline & Sales Rep. & 12.13 & 3.29 & 203 \\
\hline & Sales Mgr. & 13.18 & 3.67 & 239 \\
\hline & & & & \\
\hline 35 years & Sales Rep. & 10.09 & 2.64 & 98 \\
\hline 35 years & Sales Mgr. & 10.79 & 2.35 & 117 \\
\hline & & & & \\
\hline 55 years & Sales Rep. & 14.04 & 2.62 & 105 \\
\hline
\end{tabular}




\begin{tabular}{|l|l|c|c|c|}
\hline 55 years & Sales Mgr. & 15.47 & 3.22 & 122 \\
\hline & & & & \\
\hline Total & & 12.70 & 3.53 & 442 \\
\hline
\end{tabular}

The ANOVA results reported in Table 2 indicate that both age and occupation are statistically significant predictors of negotiated notice awards (the main effects for both age and occupation are statistically significant) but that age is clearly the more potent factor. The interaction between age and occupation was statistically significant (the p-value was below the conventional .10 threshold) and the results suggest that occupation is a more salient factor for the older versus the younger age cohort.

The experiment does not necessarily reflect the reality of actual negotiated outcomes where the parties are frequently represented by legal counsel and, of course, only concerns two Bardal factors (age and occupation). However, as will be seen, the experimental results closely track the results of the statistical analysis of the appellate court decisions.

TABLE 2: ANALYSIS OF VARIANCE RESUlts

\begin{tabular}{|l|r|r|r|l|}
\hline SOURCE & \multicolumn{1}{|l|}{ d.f. } & MEAN SQUARE & F-TEST & P-VALUE* \\
\hline MAIN EFFECTS & & & & \\
\hline Employee's Age & 1 & 2074.12 & 276.55 & $<.000$ \\
\hline Employee's Occupation & 1 & 120.87 & 16.12 & $<.000$ \\
\hline Two-WAY INTERACTION & & & 2.82 & \\
\hline Age x Occupation & 1 & 21.12 & & \\
\hline Within Groups & 438 & 7.5 & & \\
\hline Total & 441 & 12.47 & & \\
\hline
\end{tabular}

* The "p-value" is a statistical test measuring the probability that the observed result would occur by chance. Statisticians generally accept that the threshold for statistical significance is .10 or lower. Thus, for example, with a p-value of .01, it is expected that there is less than a 1 percent chance that the observed result occurred by chance.

\section{REASONABLE NOTICE DECISIONS ISSUED BY CANADIAN APPELlate COURTS 2000-2011}

In order to more finely identify the relative impact of the Bardal factors, all Canadian appellate court decisions dealing with reasonable notice issued during the 12-year period from 2000 to 2011 were examined. The following section addresses this aspect of the study.

\section{A. The Judicial Database}

The results reported below are based on the entire population of reasonable notice decisions issued by Canadian appellate courts during the period from 1 January 2000 to 31 
December 2011 and published in the Canadian Legal Information Institute (CanLII) database. ${ }^{36}$ In order to ensure that all of the requisite information was included for the purposes of statistical analysis, in those instances where the court's reasons were incomplete (for example, the employee's age, salary or tenure was not disclosed) or where relevant information was disclosed in a somewhat vague manner (for example, an "older employee" or a "long-serving employee"), the requisite missing information was obtained from secondary sources (for example, social media websites such as LinkedIn) and, in several instances, from the employee or their legal counsel directly.

Decisions involving fixed-term agreements or indefinite contracts where there was an express termination provision in the parties' employment contract were excluded from the database since the reasonable notice doctrine is inapplicable in either situation. Decisions where the ultimate notice award was capped due to the employee's successful mitigation efforts were also excluded unless the court indicated what the notice period would have been absent mitigation. ${ }^{37}$ This protocol reduced the database to 133 reasonable notice decisions, but in one instance, the Court's reasons were brief and the required information could not be obtained. Thus, the results reported here are based on 132 appellate court decisions. There were about 11 appellate court awards in each year with the number of awards ranging from 7 (in 2007) to 21 (in 2004).

\section{B. METHODOLOGY}

Based on a content analysis of the appellate decisions (and in many instances, a further review of the trial judge's decision), and also frequently using other third party sources, information was obtained regarding the following matters that, in each case, were specified as at the date of the employee's dismissal:

(i) the employee's age in years and by age category: 34 years or less; 35-49 years; 50 years or more;

(ii) the employee's tenure in years and by tenure category: short-term (less than 5 years); medium-term (5-14 years); and long-term (15 years or more);

In a personal communication, a CanLII official assured me that every effort is made to ensure complete coverage although there might be some missing decisions - for example, an oral decision that was never transcribed.

37 Wrongfully terminated employees have a "duty to mitigate"; in other words, the dismissed employee must make a reasonable effort to find comparable new employment. If the employee secures new employment prior to the expiration of the reasonable notice period, the damages payable by the employer are reduced to reflect the wages earned during the notice period. Similarly, if the employee reasonably could have, but actually did not, secure new employment during the notice period, a reduction in the damages payable will still be ordered to reflect this notional "avoidable" income loss. See Red Deer College v Michaels, [1976] 2 SCR 324; Evans v Teamsters Local Union No 31, 2008 SCC 20, [2008] 1 SCR 661. 
(iii) the natural logarithm of the employee's annual salary ${ }^{38}$ specified in thousands and converted to 2011 dollars, ${ }^{39}$ and by salary category: lower wage earners (less than $\$ 70,000) ;{ }^{40}$ medium wage earners $(\$ 70,000-\$ 124,000)$; and high wage earners (\$125,000 or more);

(iv) the employee's occupation, specified as a series of dummy variables (coded 0 or 1 depending on whether the employee fell into the individual occupational category) reflecting five separate job classifications: Clerical/Labourer; Technical/Sales; Professional (for example, lawyers, engineers, and accountants employed in their professional capacity); Lower/Middle Management; and Senior Management;

(v) the average provincial or territorial unemployment rate ${ }^{42}$ as reported by Statistics Canada for the year in which the employee was dismissed based on the employee's age category (either 25-44 years or 45-64 years) and gender; and

(vi) the employee's work record (coded as a dummy variable: $1=$ poor record as identified in the court's reasons for decision; $0=$ otherwise).

The employee's age, tenure, occupation and, to a degree, the provincial or territorial unemployment rate directly capture several Bardal factors. ${ }^{43}$ The employee's salary, together with the employee's occupation, can be considered proxies for the character of employment. None of the variables explicitly measure the employee's experience, training and qualifications although tenure, salary, and occupational category reflect these factors, at least

The employee's annual salary figure includes non-discretionary bonuses but not the value of employment benefits. For those employees who were primarily paid by contingent performance-based compensation systems, the salary figure used was the employee's total earnings in the year prior to dismissal. The employee's salary was converted to its natural logarithm because salary is typically exponentially distributed - in other words, the greater share of total employment income is earned by a relatively small group of employees. Transforming each employee's salary to its natural logarithm provides more reliable and more readily interpretable coefficient estimates.

39 Each employee's annual salary was converted to 2011 dollars in order to standardize the database. In the absence of standardization, the salary coefficients estimated by the regression equations would not be unbiased estimates. The employees' annual salary figures were converted to 2011 dollars using the Statistics Canada "Core CPI" measure as of June in each year (i.e., the mid-point of each year). For more information and data source see: Bank of Canada, “Consumer Price Index, 2000 to Present," online: $<$ www.bankofcanada.ca/rates/price-indexes/cpi>.

40 One might rightly object to characterizing a person earning $\$ 69,000$ per annum as a "lower wage" employee. However, for the most part, wrongful dismissal litigation (at least at the appellate level) is an activity reserved for the comparatively well-paid. Of the 132 employees in this study, 73 (55.3 percent) had annual salaries (in 2011 dollars) of $\$ 70,000$ or more. By contrast, currently only about 20 percent of employees earn a salary of $\$ 70,000$ or more Canada-wide.

41 According to recent Statistics Canada data, these thresholds represent the bottom 87.3 percent, the next 10.3 percent, and the top 2.5 percent, respectively, of all Canadian wage earners; see "Charting the wage gap between Canada's 99\% and top 1\%," CBC News (9 November 2011), online: <www.cbc.ca/news2/ interactives/canada-income/index.html>. Statistics Canada data for all Canadian income earners for 2011 indicate that 86.7 percent had incomes below $\$ 75,000$; 13.3 percent had incomes of $\$ 75,000$ or more; 6.3 percent had incomes of $\$ 100,000$ or more; and 2.2 percent had incomes of $\$ 150,000$ or more. See Statistics Canada, "Table 111-0008: Neighbourhood income and demographics, taxfilers and dependents with income by total income, sex and age group," CANSIM (database), online: <www5.statcan.gc.ca/ cansim/a26?id=1110008\&retrLang=eng\&lang=eng $>$.

42 The unemployment rate, expressed as a percentage (rounded to the nearest tenth of a percent), is based on the number of unemployed civilian, non-institutionalized persons in the applicable age and gender category who are actively seeking work as compared to total employment in the relevant labour market segment as whole.

43 Bardal, supra note 16 ("reasonableness of notice must be decided ... having regard to the character of employment, the length of service..., the age of the [employee] and the availability of similar employment, having regard to the experience, training and qualifications of the [employee]" at 145). 
in part. Labour market evidence regarding the availability of similar employment is very rarely placed before the court in wrongful dismissal cases save for those occasions where the employer is arguing that the employee could have successfully mitigated their damages by a more determined job search. ${ }^{44}$ Ideally, the court should have before it evidence about the labour market (which may be local, provincial, national or, in some unique cases, even international in scope) for the dismissed employee's particular occupation but Statistics Canada does not systematically collect this information. Accordingly, the provincial or territorial unemployment rate based on the dismissed employee's age and gender was used.

The dismissed employee's work record is not an enumerated Bardal factor and Canadian courts have emphasized that the quality of the employee's service should not be taken into account when fixing a reasonable notice period. ${ }^{45}$ Nevertheless, at least one prior study found that an employee's poor work record resulted in a lower notice award. ${ }^{46}$ Accordingly, a dummy variable was included in the regression model indicating whether the court commented on the employee's poor work record in its reasons for decision. Since this variable takes a value of 1 only if the court actually identified the employee as having had a poor record, this variable likely represents a downward biased estimate. ${ }^{47}$

\section{DESCRIPTIVE STATISTICS}

The mean age of the dismissed employees was 46.6 years (standard deviation: 9.4 years) and ranged from 25 to 67 years as at the date of dismissal. Fourteen employees were 34 years or less at the time of dismissal, 61 employees were 35 to 49 years of age and 57 were 50 years of age or older when dismissed. The employees were predominantly male (105 employees or 79.5 percent) and had relatively long service at the point of discharge (mean

It should be noted that the "availability of similar employment" is not equivalent to the likely time frame within which the dismissed employee will find new comparable employment. See Hunter v Northwood Pulp and Timber Ltd (1985), 62 BCLR 367, Anderson JA (CA) ("[t]he lack of available employment opportunities resulting from a depressed economy is a factor to be taken into account ... [but that this factor] must not be given undue emphasis” at 375). See also Dey $v$ Valley Forest Products Ltd (1995), 162 NBR (2d) 207 (CA); Kerfoot v Weyerhaeuser Co, 2013 BCCA 330, 46 BCLR (5th) 315, Saunders JA (if the dismissed employee faces a buoyant labour market, that fact should not be reflected in a reduced notice period but rather, should be addressed as a "mitigation issue" at para 44).

45 See e.g. Helbig v Oxford Warehousing Ltd (1985), 51 OR (2d) 421 (CA), leave to appeal to SCC refused, 19524 (10 December 1985) [Helbig]; Ansari, supra note 28.

46 Terry H Wagar, "Determinants of Just Cause and Reasonable Notice in the Dismissal of Nonunion Employees" (1996) 4:2 Can Business Economics 36. See also Terry H Wagar, "Wrongful Dismissal in Small and Medium-Sized Firms: Some Empirical Evidence” (1995) 12:2 J Small Business \& Entrepreneurship 94 (this study also found that an employee's poor work record was negatively associated with notice awards but the finding was not statistically significant); Lam \& Devine, supra note 31 (included separate dummy variables for both good and bad performance as identified in the court's reasons for decision in their regression analyses and neither variable was statistically significant). At one time, some Canadian courts accepted the notion of "near cause." In other words, where the employee's misconduct fell short of just cause, the court would deal with that behavior by way of a reduction in the notice period it would otherwise have ordered: see e.g. Babcock $v$ Weickert (C \& R) Enterprises Ltd (1993), 126 NSR (2d) 170 (CA); Judge v Pelham (Town) (1995), 9 CCEL (2d) 134 (Ont Ct J (Gen Div)); Fleming v Safety Kleen Canada Inc (1996), 20 CCEL (2d) 140 (Ont Ct J (Gen Div)). But see Dowling v Halifax (City), [1998] 1 SCR 22 at 23 (the Supreme Court of Canada unequivocally rejected the near cause doctrine).

47 In addition, the nature of the database may tend to exclude employees who are poor performers since reasonable notice cases are most commonly argued on the basis that there is no just cause. Employees who are poor performers may be less likely to appear in the database either because these individuals may choose not to pursue litigation when terminated, or they may have resigned their position rather than face a potentially more damaging termination. 
tenure: 13.0 years; standard deviation: 10.4 years) with tenure ranging from 3 months to 42 years.

The mean salary was also relatively high at $\$ 132,768$ (standard deviation: $\$ 117,970$ ) in 2011 dollars (\$2011). The employees’ individual annual \$2011 salaries ranged from just under \$20,000 to nearly \$1.6 million. As for their occupational distribution, 15 employees were in the clerical/labourer category, 43 in the technical/sales category, nine in the professional category, 49 in the lower/middle management category and 16 were in senior management positions. The employees' mean ages were quite consistent across all five occupational categories with a range of 45.5 years (technical/sales) to 48.4 years (lower/middle management).

The mean unemployment rate during the 12-year period in question was 5.9 percent (standard deviation: 1.9 percent) and ranged from a low of 2.4 percent (Alberta, 2007) to a high of 14.9 percent (Newfoundland, 2002). The provincial and territorial unemployment rates closely tracked the relative strength of the country's regional economies throughout the period with Alberta generally having the lowest unemployment rates and the four Atlantic provinces having the highest rates. The court commented on the employee's poor work record in only 24 of the 132 cases (18.2 percent).

As is apparent from Table 3, reasonable notice awards appear to be strongly influenced by both age and tenure. The table suggests that mean notice awards tended to increase in about 5-month increments from the lowest to the highest age category. Not surprisingly, mean salaries also increased with both age and tenure and this effect produces a double benefit for older employees since their relatively longer notice periods will result in comparatively higher severance awards since severance pay is essentially based on a “months' notice x salary” calculation.

TABLE 3: MEAN TENURE, SALARY, and Reasonable Notice Award by Age Category

\begin{tabular}{|l|c|c|c|}
\hline \multicolumn{1}{|c|}{ Age Category } & MeAN TENuRE & MEAN SALARY (\$2011) & MEAN NotiCE AWARD \\
\hline less than 35 years & 4.3 years & $\$ 67,778$ & 6.5 months \\
\hline $35-49$ years & 10.0 years & $\$ 111,264$ & 11.0 months \\
\hline 50 years or more & 18.4 years & $\$ 174,420$ & 16.5 months \\
\hline
\end{tabular}

\section{REGRESSION RESULTS}

Although Table 3 suggests that there is a direct relationship between age and reasonable notice (that is, older employees receive more notice), the independent impact of age can be more precisely identified by a multivariate statistical analysis of the data. In order to identify the separate impact of age on reasonable notice awards, the 132 appellate court decisions were analyzed using multiple linear regression with the coefficients estimated by the ordinary least squares method. Multiple regression is a statistical technique commonly utilized to identify the separate impact of two or more independent variables on a single dependent 
variable. The dependent variable in this study was the final reasonable notice award issued by the appellate court (in months) and the independent variables included age, tenure, occupation, salary, the provincial or territorial unemployment rate, and the employee's work record as identified in the court's reasons for decision. ${ }^{48}$

The regression results are reported in Table 4. Three separate regression equations were estimated. The first includes age, tenure, and the natural log of the \$2011 salary together with the occupational dummy variables, the unemployment rate, and the employee's work record. The second equation is essentially identical to the first save that age, tenure, and salary were specified as categorical variables. The third equation represents a condensed model excluding both the unemployment rate and work record variables inasmuch as neither variable was statistically significant in the first two equations.

The three equations are almost identical in their explanatory power with the independent variables explaining about three-quarters of the variance in the appellate courts' reasonable notice awards (see the $\mathrm{R}^{2}$ values). Since the dependent award is the actual notice period (expressed in months), the individual coefficients reflect the independent effect of a given variable (expressed in months) on the total notice award in a particular case. Clearly, both tenure and age are significant independent explanatory variables. Employees with relatively short tenure (less than 5 years) received nearly 3 months' less notice than employees with 5 to 14 years' service and employees with 15 or more years' service received about 7.5 months' more notice than employees in the mid-tenure group. Interestingly, only the $50+$ age category is statistically significant with employees in this group receiving about three additional months' notice relative to younger employees. It is important to note that this effect is independent of tenure; thus, even relatively short-service 50+ employees benefit from this 3-month age premium. Among the occupational variables, only the management categories are statistically significant and the impact is about equal for both the lower/middle and senior management categories with employees in each case receiving about 1.5 to 2.5 months of additional notice relative to all other occupational categories. Employees earning $\$ 70,000$ or more per annum received about 2 months' extra notice relative to employees earning less than $\$ 70,000$.

Neither the unemployment rate nor the employee's poor work record appeared to have any impact on the courts' notice assessments. The unemployment rate variable was not statistically significant and this result may simply reflect that it is a poor proxy for the Bardal factor "availability of similar employment”; on the other hand, this Bardal factor may not be particularly salient when fixing notice awards. The employee's work record is not an enumerated Bardal factor and the courts have repeatedly stressed that this matter should not be taken into account when fixing the reasonable notice period. ${ }^{49}$ Accordingly, the fact that this variable was not statistically significant is consistent with established jurisprudence.

48 There are commercially available research tools that can be used to predict notice awards based on certain critieria, but these tools do not utilize regression analysis: see e.g. Ellen E Mole, ed, Wrongful Dismissal Notice Searcher, CD-ROM (Markham: LexisNexis Canada, 1997); Barry B Fisher, Wrongful Dismissal Database Online (Toronto: Thomson Reuters, 2007), online: <www.wrongfuldismissal database.com>. The advantage of the latter technique is that it allows one to identify the unique independent impact of a particular Bardal factor on the determination of a global reasonable notice award.

Helbig, supra note 45 at 431; Ansari, supra note 28 at para 22. 
The results indicate that a 35-year-old middle manager, with 4 years' service and earning $\$ 60,000$ per annum (in 2011 dollars) could expect to receive a 6 -month notice award. ${ }^{50}$ By contrast, a 55-year-old middle manager, with 15 or more years’ service, earning $\$ 90,000$ per annum, would receive about 21 months’ notice. ${ }^{51}$ The mean notice award for employees under the age of 35 was 6.5 months while the mean notice award for employees 50 years of age or older was 16.4 months. Although age is positively correlated with tenure $(r=.56),{ }^{52}$ it appears that Canadian appellate courts are awarding employees 50 years of age or older an additional notice component, separate from that associated with tenure, perhaps recognizing that these older employees will have a particularly difficult time when searching for new work.

TABLE 4: OLS REgRESSION RESULTS

\begin{tabular}{|l|c|c|c|}
\hline \multicolumn{1}{|c|}{ VARIABLE } & $\begin{array}{c}\text { EQUATION No. 1 } \\
\text { (COEFF.STD. ERROR) }\end{array}$ & $\begin{array}{c}\text { EQUATION No. 2 } \\
\text { (COEFF./STD. ERROR) }\end{array}$ & $\begin{array}{c}\text { EQUATION No. 3 } \\
\text { (COEFF./STD. ERROR) }\end{array}$ \\
\hline Intercept & $-2.595(2.618)$ & $5.200(1.686)^{* *}$ & $6.61(1.26)^{* *}$ \\
\hline & & & \\
\hline Age & $.075(.041) \dagger$ & & $.290(1.075)$ \\
\hline Age (35 - 49 yrs.) & & $.461(1.083)$ & $2.812(1.166)^{*}$ \\
\hline Age ( $\geq 50$ yrs.) & & $3.138(1.190)^{* *}$ & \\
\hline & & & \\
\hline Tenure & $.461(.036)^{* *}$ & & $-2.867(.831)^{* *}$ \\
\hline Tenure (<5 yrs.) & & $-2.847(.832)^{* *}$ & $7.478(.849)^{* *}$ \\
\hline Tenure ( $\geq 15$ yrs.) & & $7.640(.865)^{* *}$ & \\
\hline & & & $1.222(1.090)$ \\
\hline Occupation (Tech/Sales) & $.894(1.079)$ & $1.240(1.091)$ & $-.094(1.598)$ \\
\hline Occupation (Professional) & $.727(1.543)$ & $-.305(1.611)$ & $2.589(1.149)^{*}$ \\
\hline Occupation (Low/Mid Mgmt.) & $3.102(1.090)^{* *}$ & $2.519(1.154)^{* *}$ & \\
\hline Occupation (Sr. Mgmt.) & $3.570(1.549)^{*}$ & $2.636(1.461) \dagger$ & $2.724(1.448) \dagger$ \\
\hline & & & \\
\hline InSalary (\$2011) & $.761(.478)$ & & \\
\hline
\end{tabular}

50 The dismissed employees in Bavaro v North American Tea, Coffee \& Herbs Trading Co, 2001 BCCA 149, [2001] 4 WWR 34; and Schurman, supra note 15, both received 6-month notice awards. Bavaro was a 35-year old purchasing manager, with 14 months' service and earning an annual salary of \$60,000 when he was dismissed on 31 December 1998. Schurman was a 37-year-old golf professional with four years' service, earning about \$34,000 per year, when he was dismissed in 2007.

51 See Coutts v British Columbia, 2000 BCCA 565, 80 BCLR (3d) 279 (56-year-old middle manager earned about \$47,000 at the time of his 1997 termination after 15 years' service, was awarded 22 months' notice); Rickards Estate v Diebold Election Systems Inc, 2007 BCCA 246, 9 WWR 117 (53year-old middle manager, with 21 years' service and earning about $\$ 141,000$ per annum when dismissed in 2002, was awarded 21 months' notice).

52 A correlation coefficient measures the strength of the association between two variables and ranges from -1 (perfectly, but inversely, correlated) to +1 (a perfect direct correlation). A value of 0 indicates that there is absolutely no covariance relationship between the two variables. The observed .56 correlation is below the critical .70 threshold that Dormann et al identified as presumptively establishing a collinearity problem: see Carsten F Dormann et al, "Collinearity: a review of methods to deal with it and a simulation study evaluating their performance” (2013) 36:1 Ecography 27. Separate equations were estimated that included only age or tenure. For each equation, the adjusted $\mathrm{R}^{2}$ values were well below the adjusted $\mathrm{R}^{2}$ value when both variables were included. This suggests that age and tenure, although associated, are nonetheless essentially independent factors affecting notice awards. 


\begin{tabular}{|l|c|c|c|}
\hline \multicolumn{1}{|c|}{ VARIABLE } & $\begin{array}{c}\text { EqUATION No. 1 } \\
\text { (COEFF.STD. ERRoR) }\end{array}$ & $\begin{array}{c}\text { EqUATION No. 2 } \\
\text { (COEFF./STD. ERROR) }\end{array}$ & $\begin{array}{c}\text { EqUATION No. 3 } \\
\text { (COEFF./STD. ERROR) }\end{array}$ \\
\hline Salary $(\$ 70 \mathrm{~K}-\$ 124 \mathrm{~K})$ & & $1.961(.866)^{*}$ & $1.989(.857)^{*}$ \\
\hline Salary $(\geq \$ 125 \mathrm{~K})$ & & $1.899(.874)^{*}$ & $1.823(.866)^{*}$ \\
\hline & & & \\
\hline Unemployment Rate & $.113(.165)$ & $.175(.165)$ & \\
\hline & & & $.603(.854)$ \\
\hline Poor Work Record & $-.006(.833)$ & & .743 \\
\hline & & .747 & .722 \\
\hline R2 & .746 & .722 & $35.051^{* *}$ \\
\hline R2 Adjusted & .727 & $29.335^{* *}$ & \\
\hline F-ratio & $39.744^{* *}$ & & \\
\hline
\end{tabular}

${ }^{* *} \mathrm{p}<.01 ;{ }^{*} \mathrm{p}<.05 ; \mathrm{\dagger p}<.10 ; \mathrm{N}=132$; standard errors in brackets. The reference categories are: Age ( $\leq 34$ years),

Tenure (5-14 years), Occupation (clerical/labourer) and Salary $(<\$ 70,000)$.

\section{Discussion and Public Policy Implications}

The negotiation experiment results indicate that age is a more salient Bardal factor than occupation, although it must also be recognized that the negotiators in the experiment were business students, not practicing lawyers, and thus the experimental results may not be generalizable to real-world negotiations. That said, the experimental results were fairly close to those predicted by the regression model — in three of the four scenarios, the experimental results were within 1.97, 1.47 and .69 months of the result predicted by the condensed model. The fourth result was about 3.4 months higher than predicted by the equation, but still close enough such that if it were a trial judgment under appeal, the appeal court would probably not overturn it. In the case of the other three scenarios, it is virtually certain that an appellate court would not intervene had the negotiated award been issued by a trial judge. ${ }^{53}$

The regression analyses of the appellate court decisions also show that age, especially for those employees 50 years of age or more, tends to trump occupation when judges are determining reasonable notice. Canadian appellate courts awarded managers about 1.5 months' more notice than employees in technical/sales positions (not very far off the results obtained in the negotiation experiment where the mean premium for managers was about 1.1 months' notice) but gave employees 50 years or older about 3 months' more notice than younger employees (compared to a mean premium for the older employee cohort of about 4.3 months in the experimental results).

The regression results are based on appellate, rather than trial, decisions. Appellate court decisions reflect the view of, typically, three justices and, of course, have greater precedential value than trial court decisions. However, most trial decisions are not appealed and it is 
possible that a sample of trial decisions could produce different results. ${ }^{54}$ That said, the regression results showed that older, relatively long service (15 or more years) employees can expect to recover about 10.5 months' notice solely on account of these two Bardal factors with tenure apparently being the more significant factor. As previously noted, dismissed employees who were at least 50 years old, and independent of tenure, recovered about 3 months' additional notice by reason of their older age. This latter result undoubtedly reflects a judicial recognition that older employees face a difficult job search following dismissal. Since "the purpose of reasonable notice is to give the employee a fair opportunity to obtain re-employment instead of being thrown suddenly and unexpectedly upon the world," 55 it seems appropriate that courts award older employees some additional notice on account of their age reflecting their unique job search hurdles.

Even though Canadian courts appear to be favourably disposed toward older employees when it comes to determining their notice entitlements, involuntary job loss can impose devastating economic and psychological costs on an older employee that may not be fully remedied by a notice supplement. ${ }^{56}$ Following dismissal, "older workers, relative to their younger counterparts, return to work at lower rates, are less successful at returning to the earnings levels achieved before they lost their jobs, and are less likely to have sustained employment after returning to work." ${ }^{57}$ Not surprisingly, older workers are pessimistic about their re-employment prospects and are much more willing than younger workers to accept new employment at a much lower wage compared to their former job. ${ }^{58}$ Older workers have disproportionate levels of long-term unemployment and when they do find new work, it is more likely to be non-standard work such as part-time work, casual employment and self-

According to the 2013 Annual Report from the British Columbia Supreme Court, 54,015 new civil cases (excluding family matters) were filed in 2013 but there were only 459 civil trials (excluding family matters) during that same year (supra note 8 at 51, 61). Statistics from the 2013 British Columbia Court of Appeal show that the appellate court received 587 civil appeals and issued 315 civil appeal judgments (excluding family matters): British Columbia Court of Appeal, 2013 Annual Report, (2014) at 39, 50, online: < www.courts.gov.bc.ca/Court_of_Appeal/about_the_court_of_appeal/annual_report/2013\%20 Annual\% 20Report.pdf $>$.

$55 \quad$ Cronk, supra note 15 at 531.

56 The 59-year old employee in Wallace, supra note 16, a leading Canadian employment law case, suffered severe psychological trauma following his dismissal. One might dismiss this situation as an isolated circumstance but many older employees have chronic health problems and the loss of employer-funded health insurance can cause significant stress and anxiety: see Angella MacEwen, "Working After Age 65: What is at Stake?,” Canadian Centre for Policy Alternatives (16 April 2012), online: <www. policyalternatives.ca/publications/reports/working-after-age-65>; Ralph E Smith, "Disability and Retirement among Aging Baby Boomers" in Eberts \& Hobbie, supra note 5, 101. Indeed, one study found that post-employment mortality rates for older male employees increased by 44 percent in the four years immediately following job loss: Marcus Eliason \& Donald Storrie, “Does Job Loss Shorten Life?” (2009) 44:2 J Human Resources 277 at 284.

57 Christopher J O’Leary \& Randall W Eberts, “Reemployment and Earnings Recovery among Older Unemployment Insurance Claimants” in Eberts \& Hobbie, supra note 5, 59 at 80. Several studies corroborate these authors' observations. For information about older workers' poor reemployment prospects, see Sewin Chan \& Ann Huff Stevens, "Job Loss and Employment Patterns of Older Workers” (2001) 19:2 J Labor Economics 484; Barry T Hirsch, David A MacPherson \& Melissa A Hardy, “Occupational Age Structure and Access for Older Workers” (2000) 53:3 Indus \& Lab Rel Rev 401; Richard W Johnson \& Janice S Park, “Can Unemployed Older Workers Find Work?,” Urban Institute (January 2011), online: <www.urban.org/UploadedPDF/412283-Unemployed-Older-Workers. $\mathrm{pdf}>$. For information regarding income loss even if new employment is secured, see Kenneth A Couch, Nicholas A Jolly \& Dana W Placzek, "Earnings Losses of Older Displaced Workers: A Detailed Analysis With Administrative Data” (2009) 31:1 Research on Aging 17; Marie Howland \& George E Peterson, “Labor Market Conditions and the Reemployment of Displaced Workers” (1988) 42:1 Indus \& Lab Rel Rev 109; MacEwen, supra note 56.

58 Statistics Canada, "The job search of the older unemployed," by André Bernard, in Perspectives on Labour and Income, vol 24 No 3, Catalogue No 75-001-X (Ottawa: Statistics Canada, 22 August 2012), online: <www.statcan.gc.ca/pub/75-001-x/2012003/article/11698-eng.pdf>. 
employment. ${ }^{59}$ A recent Statistics Canada study, based on the Longitudinal Worker File (a database comprising a 10 percent random sample of all individuals with positive employment or self-employment income in any year from 1983 to 2010), concluded that while 17 percent of men who lost long-term employment (defined as 12 years' or more tenure) between ages 50 to 54 years never re-entered the workforce, 53 percent of men aged 60 to 64 when they lost their jobs never returned to paid employment. Further, even when these men found paid employment, it was typically at much lower wage levels compared to their former jobs; similar patterns prevailed for women in the same age cohorts but women were even less likely to return to paid employment following long-term job loss. ${ }^{60}$

Some might argue that a 3-month notice supplement for older workers hardly compensates the older dismissed employee for the actual economic and other psychological costs they sustain following a without cause dismissal. ${ }^{61}$ The older worker's precarious position is greatly ameliorated in the unionized sector where job security is often protected by seniority provisions in the collective bargaining agreement and, at least in Canada, by a right of reinstatement where the dismissal is without just cause.$^{62}$ However, the union density rate, especially in the private sector, is at record lows in both Canada and the US with approximately 1 in 10 private sector employees covered by a collective bargaining agreement in Canada and only about 1 in 15 in the US. ${ }^{63}$ The Canadian federal government, recognizing the precarious position of older workers affected by involuntary job loss, has instituted the “Targeted Initiative for Older Workers," a program designed to assist displaced workers between 55 and 64 years of age in finding new work. ${ }^{64}$

The leading edge of the baby boom generation (generally understood to include those born between the mid-1940s and the mid-1960s) is now reaching conventional retirement age at a time when, in Canada, mandatory retirement has largely been abandoned. Some employers

Human Resources and Social Development Canada, Supporting and Engaging Older Workers in the New Economy, by The Expert Panel on Older Workers, Catalogue No H54-105/2008E-PDF (Ottawa: HRSDC, 2008), online: <publications.gc.ca/collections/collection_2010/rhdcc-hrsdc/HS4-105-2008eng.pdf $>$.

$60 \quad$ Statistics Canada, “Employment Transitions Among Older Workers Leaving Long-term Jobs: Evidence from Administrative Data,” by Anita Bonikowska \& Grant Schellenberg, in Analytical Studies Branch Research Paper Series, Social Analysis Division, Catalogue No 11F0019M-No 355 (Ottawa: Statistics Canada, 28 January 2014), online: <www.statcan.gc.ca/pub/11f0019m/11f0019m2014355-eng.pdf>.

61 Recent research suggests that older workers are more vulnerable to workplace bullying than other age cohorts - perhaps triggered by a desire to force older, generally more highly paid, employees to resign: Misty Harris, "Older workers particularly vulnerable to bullying, expert says," canada.com (18 October 2012), online: <o.canada.com/news/national/workplace-bullying/>.

62 The Supreme Court of Canada has observed that, in the union context, reinstatement will be the norm and compensation in lieu of reinstatement should only be awarded in exceptional circumstances where the parties' employment relationship is no longer viable: Alberta Union of Provincial Employees $v$ Lethbridge Community College, 2004 SCC 28, [2004] 1 SCR 727. However, collective bargaining agreements that include mandatory retirement provisions as part of a bona fide retirement or pension plan are insulated from human rights challenges in a number of jurisdictions including British Columbia, Alberta, Saskatchewan, Ontario, Quebec, New Brunswick, Nova Scotia, Prince Edward Island, Northwest Territories, and Nunavut (see New Brunswick (HRC), supra note 7).

63 Stephen Gordon, "What does shift in union membership mean for Canada?," The Globe and Mail (5 September 2011), online: <www.theglobeandmail.com/report-on-business/economy/economy-lab/whatdoes-shift-in-union-membership-mean-for-canada/article617653> .

64 The program appears to be working: Human Resources and Skills Development Canada, Formative Evaluation of the Targeted Initiative for Older Workers: Final Report, Strategic Policy and Research Branch, Catalogue No HS28-179/2010E (Gatineau: HRSDC, June 2010), online: < www.esdc.gc.ca/eng/ publications/evaluations/skills_and_employment/2010/sp_958_07_10e.pdf $>$. For a discussion about similar initiatives in the US, see: Carl Van Horn, Kathy Krepcio \& Neil Ridley, "Public and Private Strategies for Assisting Older Workers” in Eberts \& Hobbie, supra note 5, 205. 
have argued that courts should nonetheless assume a conventional 65-year-old retirement age when fixing reasonable notice awards for older employees, but this position has not been favourably received. ${ }^{65}$

Early boomers who are dismissed without cause may increasingly turn to human rights tribunals, rather than the courts, to remedy their wrongful dismissals. ${ }^{6}$ Since Canadian human rights statutes provide for reinstatement or compensation in lieu of reinstatement, ${ }^{67}$ older claimants may find that a human rights complaint is a better option than a civil damages claim for wrongful dismissal even accounting for the 3-month notice supplement identified in this study. ${ }^{68}$ It also remains to be seen whether, in the coming decades, age will become a more powerful Bardal factor for those older workers who pursue the litigation option. ${ }^{69}$

See e.g. Filiatrault v Tri-County Welding Supplies Ltd, 2013 ONSC 3091, 10 CCEL (4th) 75, where Justice Allen noted (at para 59):

The end to mandatory retirement at age 65 was legislated in Ontario in December 2006. This brought retirement law into harmony with already existing human rights legislation and constitutional protections against age discrimination. I do not think there is a place in this social reality for an automatic presumption that persons should or would naturally retire on reaching senior age. What this means is that employers should be disinclined to ask a court, where there is no express agreement, to imply such a term in an employment contract based simply on that now time-worn presumption.

66 The age 65 cap in the British Columbia Human Rights Code, RSBC 1996, с 210 definition of "age” was removed effective 1 January 2008, about the same time that early boomers were reaching mandatory retirement. British Columbia Human Rights Tribunal statistics show that, in 2003, it dealt with only two age complaints: Annual Report 2003-2004 (Vancouver: BC Human Rights Tribunal, 2004) at 15, online: <www.bchrt.bc.ca/shared docs/annual_reports/2003-2004.pdf>. By 2012-2013 (April to March) this number had increased to 97 age-related complaints (6 percent of the Tribunal's total caseload): British Columbia Human Rights Tribunal, 2012-2013 Annual Report (Vancouver: BC Human Rights Tribunal, 2013) at 3, online: <www.bchrt.bc.ca/shareddocs/annual_reports/2012-2013.pdf >. Although the Tribunal's statistical report does not separately identify the individual complainants' ages, it may be reasonable to assume that older complainants filed a large percentage of these complaints.

See e.g. Human Rights Code, ibid, s 37; Canadian Human Rights Act, RSC 1985, c H-6, s 53. Reinstatement (effectively a form of specific performance) is not a remedy available at common law for breaches of a contract for personal services such as an employment contract.

68 See e.g. McCormick v Fasken Martineau DuMoulin LLP, 2014 SCC 39, [2014] 2 SCR 108, where a law firm partner forced out at age 65 due to the firm's mandatory retirement policy filed a human rights complaint rather than a civil court action. The claim ultimately failed only because the Court concluded that McCormick, being a partner rather than an employee, was not entitled to to file an "age discrimination in employment” complaint with the British Columbia Human Rights Tribunal.

In Hussain, supra note 21, the Court exceeded the conventional notice threshold and awarded 26 months to a 65-year-old former warehouse supervisor. The case was heard on an expedited basis before the notice period had expired and thus the Court was invited to make a contingency deduction based on the possibility that the plaintiff might find new employment before the end of the notice period. Although Justice Roberts accepted that a contingency reduction was appropriate, she also noted "that, because of his age, his chances of employment in a similar or even a related industry are remote" and "I see about a $1 \%$ chance of re-employment" at paras 16-17 [citations omitted]. Accordingly, the 26-month notice award was reduced to 25.5 months to account for the possibility of re-employment during the notice period. 